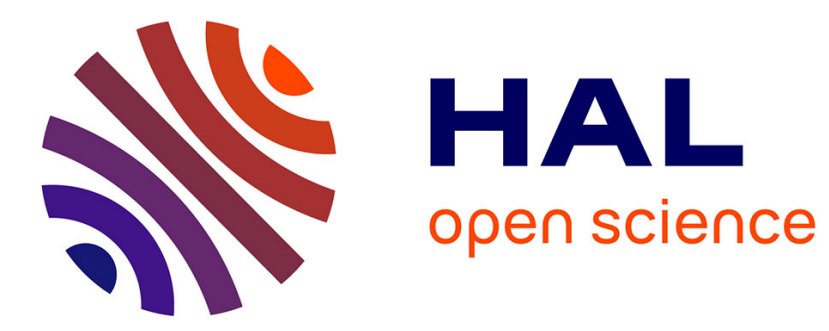

\title{
LIGHT SCATTERING INVESTIGATION OF THE FRACTAL BEHAVIOUR OF SILICA GELS
}

\author{
P. Lourdin, J. Appell, J. Pelous, T. Woignier
}

\section{To cite this version:}

P. Lourdin, J. Appell, J. Pelous, T. Woignier. LIGHT SCATTERING INVESTIGATION OF THE FRACTAL BEHAVIOUR OF SILICA GELS. Journal de Physique Colloques, 1989, 50 (C4), pp.C4197-C4-201. 10.1051/jphyscol:1989432 . jpa-00229508

\section{HAL Id: jpa-00229508 https://hal.science/jpa-00229508}

Submitted on 1 Jan 1989

HAL is a multi-disciplinary open access archive for the deposit and dissemination of scientific research documents, whether they are published or not. The documents may come from teaching and research institutions in France or abroad, or from public or private research centers.
L'archive ouverte pluridisciplinaire HAL, est destinée au dépôt et à la diffusion de documents scientifiques de niveau recherche, publiés ou non, émanant des établissements d'enseignement et de recherche français ou étrangers, des laboratoires publics ou privés. 


\title{
LIGHT SCATTERING INVESTIGATION OF THE FRACTAL BEHAVIOUR OF SILICA GELS
}

\author{
P. LOURDIN*, J. APPELL, J. PELOUS* and T. WOIGNIER*
}

Groupe de Dynamique des Phases Condensées, CNRS UA-233, Université des Sciences et Techniques du Languedoc, Place E. Batailion, F-34060 Montpellier Cedex, France

* Laboratoire de Science des Matériaux vitreux, CNRS UA-1119. Université des Sciences et Techniques du Languedoc, PIace E. Batailion, F-34060 Montpellier Cedex, France

\begin{abstract}
Résumé - L'intensité lumineuse diffusée par les gels de silice présente une dépendance, en fonction du vecteur d'onde, caractéristique des objets fractals en masse. On peut ainsi déterminer la longueur de corrélation $\xi$ au-delà de laquelle le matériau est homogene et la dimension fractale $D$. Pour des alcogels obtenus dans des conditions de catalyse basique, une valeur $\mathrm{D} \simeq 1,66$ - presque indépendante de la concentration et du veillissement - a été obtenue. $\xi$ atteint des valeurs de 1 'ordre de $200 \mathrm{~nm}$ pour les échantillons les plus légers. La comparaison de ces valeurs avec celles déduites de mesure par diffusion des neutrons aux petits angles sur la même série d'échantillons, après élimination du solvant par séchage hypercritique, i.e, des aérogels, confirme que ce séchage ne modifie pas sensiblement la texture du gel.
\end{abstract}

\begin{abstract}
The light intensity scattered by silica gels shows a wavevector-dependence characteristic of mass fractal objects. The correlation length $\xi$ beyond which the material is homogeneous and the fractal dimension $D$ can be determined.

For base catalysed alcogels a value $D \approx 1.66$ nearly independent of aging and concentration is obtained. $\xi$ rises up to $200 \mathrm{~nm}$ for the lightest sample. The comparison of these values with those obtained by small angle neutron scattering (SANS) on the same series of samples after hypercritical drying, i.e. aerogels, confirms that the drying has but little influence on the gel texture.
\end{abstract}

Scattering of light, X ray (SAXS) or neutrons (SANS) are efficient tools for studying the texture or structure of materials; in the last few years particular interest has been focused on fractal media/1/.Silica gels, wet or dried, are a class of materials for which the fractal character is now well established $/ 2,3 /$. The mass-fractal behaviour is observed between two characteristic distances $\xi$ (a correlation length) and a (a typical particle dimension). Beyond $\xi$ the density is well-defined and the material looks homogeneous. Sometimes surface-fractals are observed on restricted length range $/ 3 /$.

Up to now the published results mainly concern the sol-gel txansition and the influence of the preparation conditions (concentration of the silicium alkoxyde, catalysis conditions, ratio of water, ...) $/ 4 /$. We present here a preliminary light scattering investigation of the textural or structural changes induced by hypercritical drying. Our purpose is to compare the fractal characteristics of alcogels and aerogels prepared under the same initial conditions. Silica gels were obtained by hydrolysis and polycondensation of tetramethoxysilane (TMOS). TMOS was diluted with methanol, and four moles of a $0.05 \mathrm{~N}$ ammoniacal solution were used to perform the hydrolysis of one mole of TMOS. The samples were prepared directly in the cylindrical cells adapted to the light scattering experiments. Our study concerns low concentration of TMOS for which the fractal behaviour is expected to extend to lower $q$ values $/ 4 /$. We have used the $1 \% 2 \%$ and $4 \%$ volumic ratio of TMOS. The angular distributions of light scattered by the samples are obtained on a standard Rayleigh spectrometer. The incident light is from an Argon ion laser operating at $\lambda=4880 \AA$. The scattered 1 ight is received on a photomultiplier and its signal sent to a Brookhaven correlator which, here, simply records the number 
of counts per time unit. The angular scans are made with an AMTEC goniometer. The accessible wavevector range spans from $3 \cdot 10^{-4} \mathrm{~A}^{-1}$ to $3 \cdot 10^{-3} \mathrm{~A}^{-1}$. If the pinhole in front of the photomultiplier corresponds to about one coherence area, erratic intensity variations were observed for small scattering angle changes. These variations are similar to the speckle pattern given by a random scatterer. This behaviour, not observed in the sol where the brownian motion of particles thermally averages the signal, seems similar to those recently observed on glasses /5/. They were attributed to frozen spatial density fluctuations. Thus, angular distributions were recorded using a large pinhole in front of the photomultiplier, moreover the scattering patterns obtained for several orientations of the sample were added.

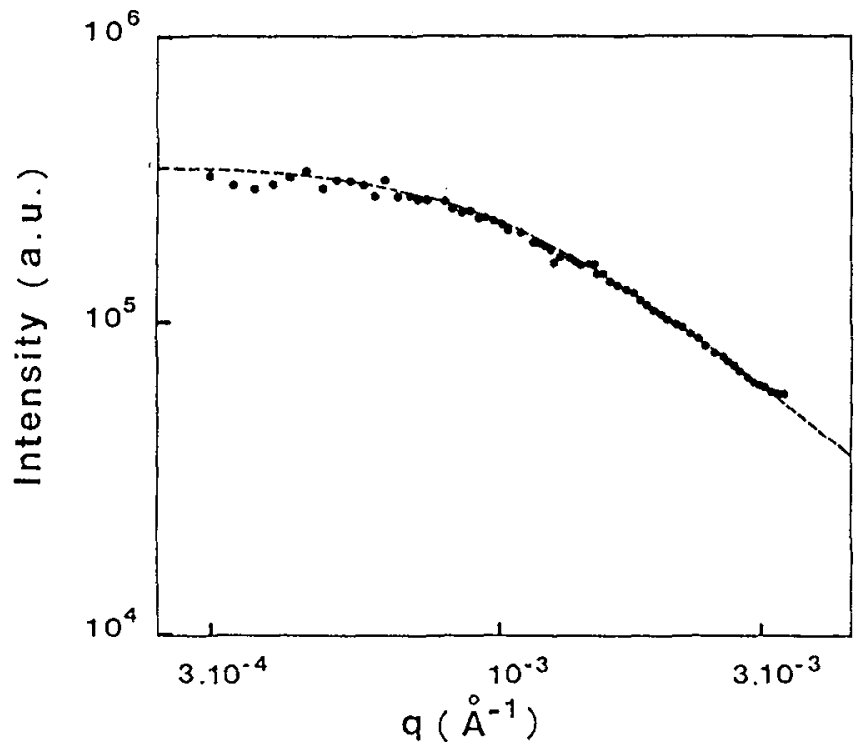

Fig.1 - Typical scattering pattern for base catalysed alcogel on a $\log -\log$ plot

* experimental

-.. best fit using the formula [1]

A typical scattering pattern is shown on Fig.l. In the fractal regime the intensity varies as $I(q) \sim q^{-D}$, so as a first approximation, the linear part of the log-log plot for the higher q values gives a direct determination of the fractal dimension $D$. The limit $\xi$ corresponding to $q \xi \approx 1$ can be estimated by the intercept of the straight lines observed on both limiting regimes at low and high $q$.

A more precise determination can be deduced from a fit with the FisherBurford relationship $/ 6 /$ successfully used previously for colloidal solutions $/ 7 /$.

1

$$
I(q) \propto \overline{\left(1+q^{2} \xi^{2}\left(\begin{array}{l}
D \\
2
\end{array}\right)\right)^{D / 2}}
$$

An example of the best fit obtained with this formula is also given in Fig. 1 .

The time evolution of the scattering pattern for the lower TMOS concentration is illustrated on Fig.2. In agreement with previous investigations $/ 4 /$, no discontinuity is observed at the sol-gel transition. $\xi$ increases with time up to $200 \mathrm{~nm}$ and a constant value $\mathrm{D} \simeq 1.65 \pm 0.05$ is observed. 


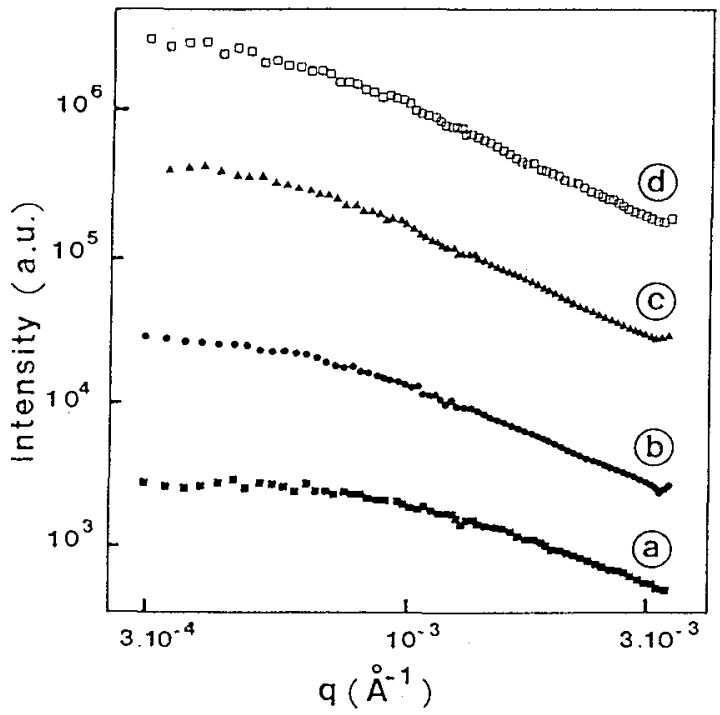

Fig. 2 - Evolution of the scattering pattern on a $\log -\log$ plot of the $1 \%$ TMOS sample during the gelation pracess. The curves are arbitrarily shifted on the $\mathrm{Y}$ axis. Time in days: $\mathrm{a}: 6 ; \mathrm{b}: 11 ; \mathrm{c}: 17 ; \mathrm{d}: 21$

\section{Table I -}

Table caption - $-\mathrm{D}$ and $\xi$ are rough determination as explained in the text. - DF and $\xi \mathrm{F}$ are obtained by a fit procedure using the formula (1) of the text.

\begin{tabular}{|c|c|c|c|c|}
\hline Volumic ratio of TMOS 8 & DF & $\xi \mathrm{F}(\mathrm{nm})$ & $\mathrm{D}$ & $\xi(\mathrm{nm})$ \\
\hline 18 & 1.66 & $196 \pm 10$ & 1,50 & $192 \pm 20$ \\
\hline 28 & 1.66 & $134 \pm 10$ & 1.46 & $174 \pm 20$ \\
\hline 48 & $(1.43)$ & $70 \pm 10$ & 1.24 & $87 \pm 20$ \\
\hline
\end{tabular}

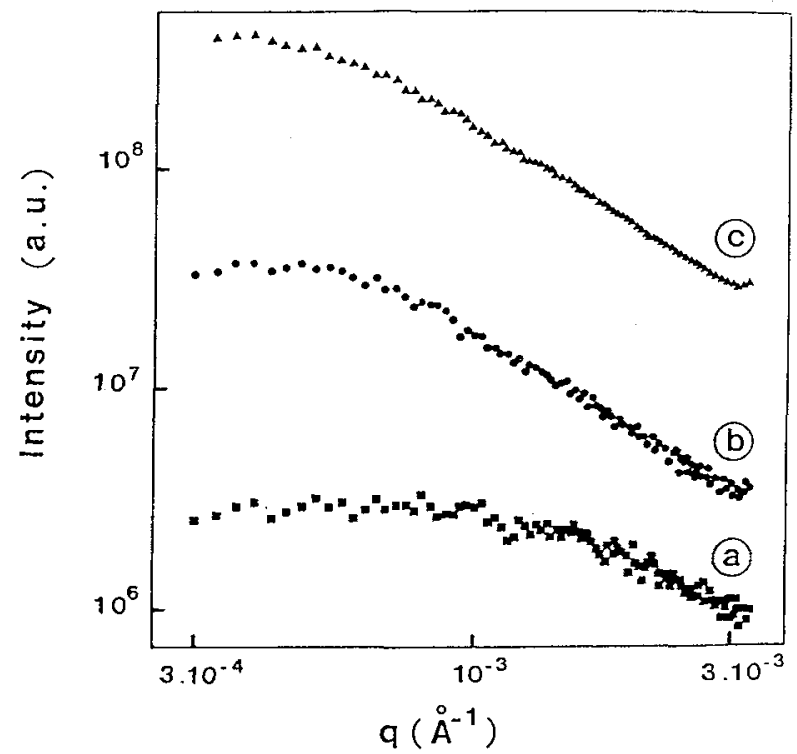

Fig.3 - Scattering pattern evolution with the volumic ratio $c$ of tetramethoxysilane (TMOS)

$$
\text { a : } 48, b: 28, \quad c: 18 \text {. }
$$


The alcogels scattering pattern changes with the TMOS concentration [Fig. 3]. shown. The values of $\xi$ and $D$ deduced from these curves, following the two procedures described above, are given on table 1. For the most dense sample ( 4 \& TMOS) studied here, the limit of the fractal behaviour is shifted to higher q-values; the light scattering pattern thus yields $\xi$ and particularly $D$ with large uncertainties.

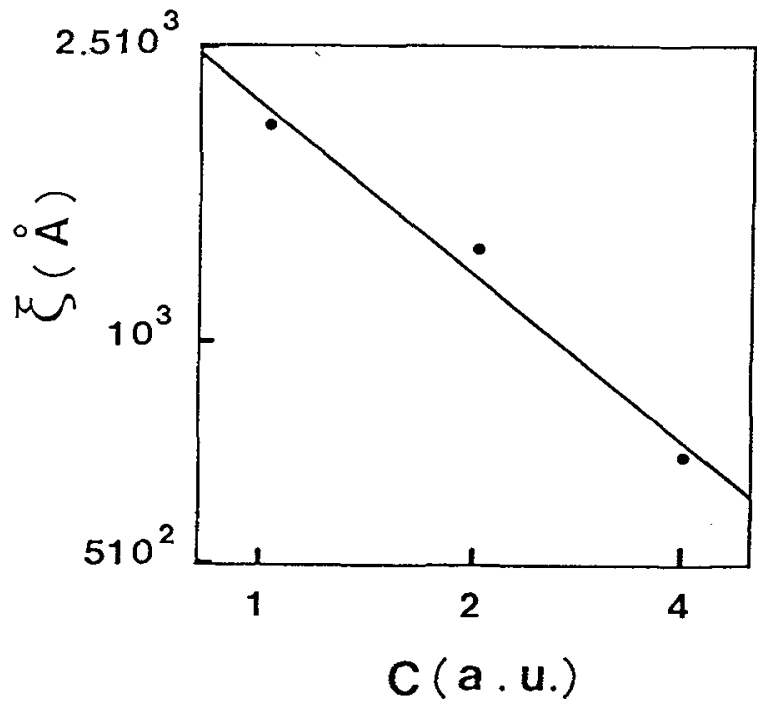

Fig. 4 - Correlation range $(\xi)$ as a function of concentration (c) of TMOS (log-log plot). The straight line corresponds to $\xi-c^{-0.75}$

The concept of mutual self similarity for a series of different gels prepared under similar conditions implies that $\rho \propto \xi^{D-3} / 2 /$ where $\rho$ is the gel density $/ 4 / . \rho$ is proportionnal to $c$ due to the low shrinkage in basic catalysis $/ 8 /$. The $\log -\log$ plot of $\xi$ as a function of $c$ [Fig.4] yields a straight line from which we deduce $\xi \sim \rho^{-0.75} / 3 /$. This demonstrates the mutual self similarity of the alcogels and from $/ 2 /$ and $/ 3 /$ we deduce $D=1.66 \pm 01$ in good agreement with the direct determination of $D$ for each sample (cf. table I).

Moreover, this value compares well with the fractal dimension $(D \simeq 1.8 \pm 0,1)$ determined by SANS performed on aerogels of the same series of samples $19 /$ : the small densification associated to hypercritical drying has but little influence on the gel texture.

\section{Références}

1/ D. Schaefer, M.R.S. Bulletin, (1988). 22.

P. Schmidt, The fractal approach of the Chemistry of disordered systems Polymers, Colloïds and Surfaces. Ed. D. Avnir. Pub. J. Wiley and Sons. Ltd. (1988) in Press.

J.E. Martin and A. Hurd, J. Appl. Cryst. 20 (1987) 61 .

J. Teixeira, in "On Growth and Form", Eds. H.E. Stanley and N.Ostrowsky, Pub. Nijhoff (1986) p. 145.

/2/ D. Schaefer and K. Keefer, Phys. Rev. Lett. $\underline{53}$ (1984) 1383.

13/ R. Vacher, T. Woignier, J. Pelous and E. Courtens, Phys. Rev. B. 37 (1988) 6500.

14/ B. Cabane, M. Dubois and R. Duplessix, J. Phys. 48 (1987) 2131.

J. Martin and K. Keefer, Phys. Rev. A. 34 (1986) 4988 .

/5/ R. Gillies, M. Kazmierczak, T. Keyes, A.J. Wojtowicz and A. Lempicki, Phys. Rev. B. 36 (1987) 9413.

/6/ M. Fisher and R. Burford, Phys. Rev. B. 10 (1974) 2818 .

/7/ G. Dietler, C. Aubert, S.D. Cannell and P. Wiltzius, Phys. Rev. Lett. $\underline{57}$ (1986) 3117. 
18/ T. Woignier, J. Phalippou, J. Non Cryst. Sol. 93 (1987) 17.

/9/ R. Vacher, T. Woignier, J. Phalippou, J. Pelous and E. Courtens, Oxnard, july 1988, Proceedings of the $\mathrm{IV}^{\mathrm{th}}$ International Conference on the Structure of Non-Crystalline Solids. To be published. 